\title{
Impact of oral and mental health over the quality of life of older people in a Family Health Unit
}

\author{
Impacto da saúde bucal e mental na qualidade de vida de \\ idosos de uma Unidade de Saúde da Família
}

\author{
Mariama Gentil MUSSOLIN1 (iD https://orcid.org/0000-0002-8249-3130 \\ Luana Pinho de MESQUITA-LAGO² iD https://orcid.org/0000-0002-9863-3062 \\ Maria Conceição Pereira SARAIVA ${ }^{3}$ iD https://orcid.org/0000-0001-6858-7029 \\ Soraya Fernandes MESTRINER ${ }^{2}$ iD https://orcid.org/0000-0002-7482-8041
}

\section{ABSTRACT}

Objective: This study sought to analyze the impact of oral and mental health on the quality of life of older people enrolled in a Family Health Unit, as well as its associated factors. Methods: This was a cross-sectional, descriptive, exploratory study, conducted through interviews. The probabilistic sample consisted of 86 older people, users of the unit, aged 60 and over, dependent or independent, from both sexes. The methodological frameworks adopted for data collection were the evaluation of oral health conditions (edentulism) and the structured interview, employing oral health perception questionnaires (SB-Brazil), the OHIP - 14 (Oral Health Impact Profile), and the PHQ-2 (Patient Health Questionnaire - Two Items) screening tool for depressive disorders. Secondary data was collected from e-SUS individual records (e-SUS Primary Care). Results: The majority of the sample (64\%) was female, between 60 and 90 years old (mean of 72.4 years). Most frequently occurring OHIP-14 dimensions were pain (16.3\%) and psychological disability (11.6\%). The variables age, income, schooling, need for and use of prostheses, activities of daily living (ADL), self-reported diseases (diabetes, hypertension and cancer) had no significant association with quality of life measures related to oral health. A good correlation and association ( $p<0.001$ ) between PHQ-2 (depressive disorders) and OHIP-14 scores was observed. Conclusion: In conclusion, an association between oral and mental health can be observed in older people; thus, for this population-especially in the case of older women oral and mental health care requires an extensive and multiprofessional approach, aimed at improving quality of life.

Indexing terms: Mental health. Oral health. Quality of Life.

\section{RESUMO}

Objetivo: O presente estudo procurou analisar o impacto da saúde bucal e mental na qualidade de vida de idosos cadastrados em uma unidade de saúde da família, e fatores associados. Métodos: Trata-se de um estudo descritivo de corte transversal de caráter

1 Universidade de São Paulo, Faculdade de Medicina de Ribeirão Preto, Residência Multiprofissional em Atenção Integral Saúde. Ribeirão Preto, SP, Brasil.

2 Universidade de São Paulo, Faculdade de Odontologia de Ribeirão Preto, Departamento de Estomatologia, Saúde Coletiva e Odontologia Legal. Ribeirão Preto, SP, Brasil.

3 Universidade de São Paulo, Faculdade de Odontologia de Ribeirão Preto, Departamento de Clínica Infantil. Av. do Café, s/n., Campus da USP, 14040-904, Ribeirão Preto, SP, Brasil. Correspondence to: SF Mestriner. E-mail: <somestri@forp.usp.br>.

$\boldsymbol{\nabla} \mathbf{v}$ v

How to cite this article

Mussolin MG, Mesquita-Lago LP, Saraiva MCP, Mestriner SF. Impact of oral and mental health over the quality of life of older people in a Family Health Unit. RGO, Rev Gaúch Odontol. 2020;68: e20200043. http://dx.doi.org/10.1590/1981-86372020000433676 
exploratório, realizado por meio de entrevistas. A amostra probabilistica foi composta de 86 usuários idosos com 60 anos ou mais, dependentes ou não, de ambos os sexos, cadastrados em uma Unidade de Saúde da Família. As estruturas metodológicas adotadas para coleta de dados foram a avaliação das condições de saúde bucal (edentulismo) e entrevista estruturada, em que foram utilizados questionários de percepção da saúde bucal (SB-Brasil), o OHIP - 14 (Oral Health Impact Profile), e o instrumento de rastreamento para transtornos depressivos PHQ-2 (Patient Health Questionnaire - Two Items); e coletas de dados secundários do Cadastro Individual (e-SUS Atenção Básica). Resultados: Na amostra, 64\% eram do gênero feminino, tinham idade entre 60 a 90 anos (média de 72,4 anos). As frequências das dimensões do OHIP-14 com maior impacto foram: dor (16,3\%) e incapacidade psicológica (11.6\%). As variáveis idade, renda, escolaridade, necessidade e uso de próteses, atividades de vida diária (AVD), doenças referidas (diabetes, hipertensão e câncer) não tiveram associação significativa com as medidas de qualidade de vida relacionada à saúde bucal. Foi observada uma boa correlação e associação entre PHQ-2 (transtornos depressivos) e os escores do OHIP-14 ( $p<0.001)$. Conclusão: Conclui-se que há associação entre saúde bucal e mental em idosos e o cuidado à saúde bucal e mental nesta população, em especial da mulher idosa, requer uma abordagem ampliada e multiprofissional, visando a melhoria da qualidade de vida.

Termos de indexação: Saúde mental. Saúde bucal. Qualidade de vida.

\section{INTRODUCTION}

The improvement in quality of life conditions, scientific progress, new technologies, better knowledge of the population and better access to health services have promoted a change in Brazil's sociodemographic profile. There has been an increase in life expectancy and a reduction in birth rate, leading to an increasing number of older people, which should grow even more over the years [1]. In this context, the challenge lies in the development of economic and social public policies to meet the needs of this new populational profile, obtaining an increasingly widespread and efficient comprehensive health care [1].

The backdrop of an aging population also means an increased occurrence of chronic non-communicable diseases, which can affect older people's autonomy and quality of life. Furthermore, the changes in the morbidity and mortality profile of this population make clear the need for the training and qualification of health professionals, as well as further debate on adequate public policies [2].

Although the indexes for infectious diseases, malnutrition, external causes and maternal conditions may be considered more worrisome, chronic diseases account for $66 \%$ of all morbidities [3]. Among non-communicable chronic diseases (NCDs), depression is the most prevalent among the older people [4], constituting a serious public health problem. Underreporting of depressive disorders makes it difficult for health professionals to diagnose them at the primary care level, which indicates the importance of actively searching for this population [5]. In addition, studies show that depression can act as a risk factor for coronary heart disease, stroke and heart failure. Thus, it is important for professionals in the Family Health Strategy to expediently detect and prevent these diseases [4].
Mental health is an important factor for the older population. The prevention and control of depressive disorders involves variables that can interfere directly or indirectly in users' quality of life. Sousa et al. [5] identified a $28.1 \%$ prevalence of depression in older people enrolled in a small municipality's FHS unit. The factors associated with symptoms of depression were being female, divorced, without religion, and having a chronic disease [5].

The aging of the population and the increase in chronic-degenerative diseases linked to disabilities and deficiencies make it necessary to evaluate older people's impairment of functional capacity, since this is essential for adequate diagnosis, prognosis and clinical decisionmaking. The development of chronic diseases and their sequelae does not interfere in individuals' life expectancy, but it may restrict functional and mental capacity during aging [6]. These changes create limitations for older people's day-to-day activities and family dynamics. In these conditions, older people may reach a stage where they are unable to perform their tasks without the help of another person, thus becoming dependent [7]. A dependent older individual requires a caregiver, who may be a professional health worker, a friend, a neighbor, or a relative (mother, father, children, grandchildren, brother, uncle etc.) [8].

In older people's routine, oral health and quality of life are interconnected; their own conceptions of these factors, however, vary according to the physical, social and emotional environment in which they are inserted. It is important to emphasize that evaluating the social impact of oral health through validated questionnaires can help healthcare managers build policies to improve quality of life, since the knowledge of subjective elements can complement clinical evaluation [9]. Thus, the knowledge of older people's self-perceived oral health may contribute 
to increasing their autonomy and quality of life, important elements for the achievement of a comprehensive health care [10].

This study aimed to analyze the impact of oral health on the quality of life of older people enrolled in a Family Health Unit, as well as possible associations between socioeconomic variables, depressive disorders, self-reported diseases, edentulism and the use of dental services.

\section{METHODS}

This was an exploratory, cross-sectional, descriptive study, conducted through interviews and clinical examination of older people, patients of a Family Health Unit (FHU) in the city of Ribeirão Preto-SP, located in the city's western area. The Unit acts as a Family Health Strategy team, and assists 740 registered families, distributed into 5 (five) micro areas, comprising a total of 2,339 people, 638 older people among them [11].

The studied population was 60 years old or over, comprised of both sexes, enrolled in the selected FHU, and mentally capable. Everyone freely consented to participating in the research. Individuals with hearing impairment or cognitive limitations that could affect their ability to answer the questionnaires were excluded.

Sample calculation considered the total number $(\mathrm{N})$ of older people enrolled in the FHU, using a 95\% confidence interval, plus 20\% to compensate for possible losses. Participants were randomly selected by systematic lottery, on the basis of e-SUS medical records. This resulted in a sample of 101 individuals.

The methodological strategy adopted for data collection was comprised of structured interviews and clinical examinations performed at participants' households. Secondary data was obtained from Primary Care e-SUS's individual medical records. In the interviews, the following literature-validated questionnaires were employed: the Oral Health Impact Profile (OHIP-14) [12], the Patient Health Questionnaire - Two items (PHQ-2) [13], Activities of Daily Living (ADL) assessment by means of the modified Katz index [14]; and the Questionnaire on Socioeconomic Conditions, use of Dental Services and Self-perception of Oral Health [15]. In addition to the interviews, a clinical epidemiological examination was carried out to evaluate oral health conditions (edentulism).
The OHIP questionnaire was developed with the purpose of providing a self-reported measure of dysfunction, discomfort and disability attributed to oral conditions. The questionnaire provides information on oral health's impact over people's quality of life, and also on the effectiveness of health services in reducing negative impacts [9]. The Likert scale was used to attribute a score to each OHIP-14 answer, with the following values: 0 = never, 1 = hardly ever, 2 = sometimes, 3 = often, $4=$ always. The maximum possible score was 56 points. The averages for each domain and for the total OHIP-14 score were recorded for further comparisons. Based on a previous study [16], responses to each OHIP-14 question were dichotomized, with 'often' or 'all the time' answers signifying the presence of an impact, and 'never,' 'hardly ever,' or 'sometimes' answers signifying no impact.

Depressive disorders were assessed via the PHQ-2 [13], which contains two items for evaluating the frequency of depressed moods and anhedonia in the last two weeks (questions one and two). Kroenke et al.[13] examined the psychometric properties of the PHQ-2 in primary care patients and gynecological clinics, and found satisfactory validity, with 0.83 sensitivity and 0.92 specificity at a 3 (three) or greater cut-off point. Given the above cut-off point, older people with PHQ-2 $\geq 3$ were considered as having disorders, and those with PHQ-2 $<3$ as having no disorders. A Brazilian research evaluated the instrument's validity for women in primary care, finding excellent results of 0.97 sensitivity and 0.88 specificity, as well as a 0.81 positive predictive value and a 0.98 negative predictive value at the 3 (three) cut-off point [17].

The modified Katz index was used to evaluate Activities of Daily Living (ADL) in dependent and semidependent older people [14]. For each affirmative answer, the participant gained a point; at the end, all points were added, with older people who obtained 0 to 2 points being considered dependent, older people who obtained 2 to 4 points being considered semi-dependent, and older people who obtained 5 to 6 points being considered independent.

Two questions from the 'Use of Dental Service' block of the Questionnaire on Socioeconomic Conditions, use of Dental Services and Self-perception of Oral Health [15] were applied in order to evaluate important subjective conditions regarding access to dental services: time since and place of the last dental appointment.

The assessment of use and need for prostheses was performed in participants' households by an examiner 
(dentist) and a score-taker, calibrated according to the WHO (World Health Organization) criteria [15]. Answers were dichotomized as 'uses' or 'does not use' a prosthesis; and 'requires' or 'does not require' a prosthesis. The evaluation of prosthetic use and need helps understand the condition of edentulism, while allowing for an estimation of the problem's severity via the combined analysis of 'use' and 'need' data, which may subsidize healthcare planning actions [15]

Socioeconomic data (sex, family income in minimum salaries, number of family members, schooling in years of study), and self-reported diseases (hypertension, diabetes and cancer) were obtained from e-SUS's individual medical record.

OHIP-14's seven domains (1: Functional limitation, 2: Physical pain, 3: Psychological discomfort, 4: Physical disability, 5: Psychological disability, 6: Social disability, 7: Handicap) were adopted as dependent variables. The independent variables were selected so as to express the association between OHIP-14's dimensions and older people's socioeconomic conditions, edentulism (use and need of prosthesis), use of dental services, activities of daily living (ADL), self-reported diseases (hypertension, diabetes, cancer) and depressive disorders (PQH-2).

The data were analyzed by means of descriptive statistics, with the distribution of absolute and percentual frequencies of all variables under study according to form (symmetry, asymmetry), central tendency (mean, median) and variability (standard deviation, total variance) [16].

For bivariate analysis, statistical tests were performed to determine the association between OHIP-14 score and independent variables. Since the distribution of the outcome (OHIP_14) was strongly skewed to the right, we categorized the variable according to percentiles in low ( $<75$ th percentile), moderate (75 to 90th percentiles) and high (> 90th percentile). Categorical explanatory variables were subjected to chi-square test or Fisher's exact test when necessary. Continuous explanatory variables without normal distributions were analyzed by KruskalWallis or Mann-Whitney test. Correlations of the OHIP and PHQ-2 dimensions, as well as the correlation of each OHIP dimension with its total score, were evaluated through the Spearman correlation test. All statistical analyzes were performed in the SAS 9.3 program, using two-tailed tests and a $5 \%$ significance level.
This study was approved by the Research Ethics Committee of the Dentistry School of the University of São Paulo, in Ribeirão Preto, under process number 2,323,286.

\section{RESULTS}

Eighty-six older people were evaluated in the period from October to December 2017. Eight older people did not agree to participate in the study, 6 were not found after three attempts and 1 died - a loss of $14.18 \%$. Age ranged from 60 to 90 years, with a mean of 72.4 years ( $S D=7.1)$, and no statistically significant association was found between OHIP categories $(p=0.44 \mathrm{Kw}$ ) or with depressive disorders $(p=0.17)$. Among participants, $64 \%$ were female, $56 \%$ had incomplete elementary education, and $64.6 \%$ had an income equal to or less than 1 minimum wage (BRL 937.00). Only 15.1\% reported having had cancer treatment, $34.9 \%$ diabetes, and $63.9 \%$ hypertension. Although not significant $(p=0.19)$, depression was more prevalent among women (30.9\%) than men (16.1\%).

Regarding dependency and independence, only $3.6 \%$ depended on a caregiver or helper to perform their activities of daily living (ADL), and $96.4 \%$ performed their activities alone, without need for assistance. Regarding edentulism, the majority reported using a superior dental prosthesis (81.2\%). The data also showed that $21.1 \%$ were in need of a superior prosthesis, and $39.5 \%$ of a lower prosthesis (both measures including the need for replacement of the currently used prostheses). Regarding the use of dental services, $45.4 \%$ had visited a dentist less than a year ago, and the majority used the private service $(57 \%)$

The OHIP score ranged from 0 to 46 with an average of 5.2 (SD = 8.2) and a median of 2 (1st Quartile $-\mathrm{Q} 1=0$ and 2nd Quartile - Q2 = 8). There was no statistically significant association between OHIP categories and age, sex, schooling, income, diabetes, cancer, hypertension, $A D L$, edentulism, and dental services: except for a statistically significant association with depressive disorders - the Spearman correlation coefficient between OHIP and PHQ-2 was $0.24(p=0.0218)$ (table 1$)$.

Among OHIP domains, those with the greatest impact on quality of life were physical pain (14\%), followed by psychological disability (10\%), psychological discomfort $(6 \%)$, and functional limitation (3\%) (Table 2). 
Table 1. Socioeconomic profile and studied variables according to Oral Health Impact Profile (OHIP-14) and depressive disorder (PHQ-2) in older people enrolled in a Family Health Unit in the city of Ribeirão Preto.

\begin{tabular}{|c|c|c|c|c|c|c|c|c|}
\hline & \multirow{2}{*}{ Total } & \multicolumn{4}{|c|}{ OHIP - 14} & \multicolumn{2}{|c|}{ Depressive Disorder (PHQ-2) } & \multirow{2}{*}{${ }^{*}$} \\
\hline & & $0-8.0$ & $8.0-15.0$ & $>15^{* *}$ & $p$ & Yes $(\geq 3)$ & No $(<3)$ & \\
\hline & n (\%) & n (\%) & n (\%) & n (\%) & & n (\%) & n (\%) & \\
\hline \multicolumn{9}{|l|}{ Sex } \\
\hline Male & $31(36.0)$ & $25(19.4)$ & $4(12.9)$ & $2(6.5)$ & 0.96 & $5(16.1)$ & $26(83.9)$ & 0.19 \\
\hline Female & $55(64.0)$ & $42(16.3)$ & $7(12.7)$ & $6(10.9)$ & & $17(30.9)$ & $38(69.1)$ & \\
\hline \multicolumn{9}{|l|}{ Schooling } \\
\hline 4 years & $56(65.1)$ & $44(78.4)$ & $7(12.5)$ & $5(8.9)$ & 0.72 & $12(21.4)$ & $44(78.6)$ & 0.41 \\
\hline $5-8$ years & $17(19.8)$ & $14(82.4)$ & $1(5.9)$ & $2(11.8)$ & & $6(35.3)$ & $11(64.7)$ & \\
\hline 9 years old & $13(15.1)$ & $9(69.2)$ & $3(23.1)$ & $1(7.7)$ & & $4(30.7)$ & $9(69.2)$ & \\
\hline \multicolumn{9}{|c|}{ Per Capita Income } \\
\hline$\leq 1 \mathrm{MW}^{* * *}$ & $53(64.6)$ & $41(77.4)$ & $7(13.2)$ & $5(9.4)$ & & $14(26.4)$ & $39(73.6)$ & \\
\hline$>1<3 \mathrm{MW}$ & $18(22.0)$ & $14(77.8)$ & $2(11.1)$ & $2(11.1)$ & 0.99 & $5(27.8)$ & $13(72.2)$ & 0.86 \\
\hline$\geq 3 \mathrm{MW}$ & $11(13.4)$ & $9(81.8)$ & $1(9.0)$ & $1(9.1)$ & & $2(18.2)$ & $9(81.8)$ & \\
\hline \multicolumn{9}{|c|}{$\begin{array}{l}\text { Depressive Disorder } \\
\text { (PHQ-2) }\end{array}$} \\
\hline Yes (3) & $22(25.6)$ & $11(50.0)$ & $5(22.7)$ & $6(27.3)$ & & & & \\
\hline No $(<3)$ & $64(74.4)$ & $56(87.5)$ & $6(9.4)$ & $2(3.1)$ & $<0.0001$ & & & \\
\hline \multicolumn{9}{|l|}{ Diabetes } \\
\hline Yes & 30 (34.9) & $21(20.0)$ & $6(20.0)$ & $3(10.0)$ & 0.37 & $6(20.0)$ & $24(80.0)$ & 0.38 \\
\hline No & $56(65.1)$ & $46(16.1)$ & $5(8.9)$ & $5(8.9)$ & & $16(28.6)$ & $40(71.4)$ & \\
\hline \multicolumn{9}{|l|}{ Cancer } \\
\hline Yes & $13(15.1)$ & $13(30.8)$ & 0 & 0 & 0.18 & $1(7.7)$ & $12(92.3)$ & 0.16 \\
\hline No & $73(84.9)$ & $54(15.0)$ & $11(15.0)$ & $8(10.0)$ & & $21(28.8)$ & $52(71.2)$ & \\
\hline \multicolumn{9}{|l|}{ Hypertension } \\
\hline Yes & $55(64.0)$ & $43(78.2)$ & $7(12.7)$ & $5(9.1)$ & 0.99 & $13(23.6)$ & $42(76.4)$ & 0.58 \\
\hline No & $31(36.0)$ & $24(77.4)$ & $4(12.9)$ & $3(9.1)$ & & $9(29.0)$ & $22(71.0)$ & \\
\hline \multicolumn{9}{|l|}{ ADL } \\
\hline Dependent & $3(3.6)$ & $1(33.0)$ & $1(33.3)$ & $1(33.3)$ & 0.27 & $3(33.3)$ & 0 & 0.01 \\
\hline Independent & $81(96.4)$ & $66(79.5)$ & $10(12.0)$ & $7(8.4)$ & & $7(22.9)$ & $64(77.1)$ & \\
\hline \multicolumn{9}{|c|}{ Superior Prosthesis } \\
\hline Does not use & $16(18.8)$ & $12(75.0)$ & $2(12.5)$ & $2(12.5)$ & & $3(18.7)$ & $13(81.2)$ & \\
\hline Uses & $69(81.2)$ & $54(78.3)$ & $9(13.0)$ & $6(8.7)$ & 0.88 & $19(27.5)$ & $50(72.5)$ & 0.46 \\
\hline \multicolumn{9}{|c|}{ Inferior Prosthesis } \\
\hline Does not use & $36(42.3)$ & $30(83.3)$ & $3(8.3)$ & $3(8.3)$ & & $8(22.2)$ & $28(77.8)$ & \\
\hline Uses & 49 (57.6) & $36(73.5)$ & $8(16.3)$ & $5(10.2)$ & 0.55 & $14(28.5)$ & $35(71.5)$ & 0.50 \\
\hline \multicolumn{9}{|c|}{ Superior Prosthesis } \\
\hline \multicolumn{9}{|c|}{ Necessary } \\
\hline Not necessary & $62(72.9)$ & $46(74.2)$ & $9(14.5)$ & 7 (11.3) & & $18(29.0)$ & $44(71.0)$ & \\
\hline Necessary & $23(21.1)$ & $20(87.0)$ & $2(8.7)$ & $1(4.3)$ & 0.51 & $3(13.0)$ & $20(87.0)$ & 0.28 \\
\hline \multicolumn{9}{|c|}{$\begin{array}{l}\text { Inferior Prosthesis } \\
\text { Necessary }\end{array}$} \\
\hline Not necessary & $52(60.5)$ & $39(75.0)$ & $7(13.5)$ & $6(11.5)$ & & $15(28.8)$ & $37(71.2)$ & \\
\hline Necessary & $34(39.5)$ & $28(82.3)$ & $4(11.8)$ & $2(5.9)$ & 0.79 & $7(20.6)$ & $27(79.4)$ & 0.39 \\
\hline \multicolumn{9}{|l|}{$\begin{array}{l}\text { Last Dentist } \\
\text { Appointment } \\
\text { (years) }\end{array}$} \\
\hline$<1$ & $39(45.4)$ & 30 (76.9) & $5(12.8)$ & $4(10.3)$ & 0.49 & $10(25.6)$ & $29(74.2)$ & 0.13 \\
\hline $1-2$ & $16(18.6)$ & $13(81.2)$ & $0(0.0)$ & $3(18.8)$ & & $4(25.0)$ & $12(75.0)$ & \\
\hline$\geq 3$ & $11(12.8)$ & $8(72.7)$ & $2(18.2)$ & $1(9.1)$ & & $6(54.5)$ & $5(45.4)$ & \\
\hline Never & $5(5.8)$ & $4(80.0)$ & $1(2.0)$ & 0 & & $0(0.0)$ & $5(100.0)$ & \\
\hline Does not know & $15(17.4)$ & $12(80.0)$ & $3(2.0)$ & 0 & & $2(13.3)$ & $13(86.7)$ & \\
\hline
\end{tabular}


Table 1. Socioeconomic profile and studied variables according to Oral Health Impact Profile (OHIP-14) and depressive disorder (PHQ-2) in older people enrolled in a Family Health Unit in the city of Ribeirão Preto.

\begin{tabular}{|c|c|c|c|c|c|c|c|c|}
\hline & \multirow{2}{*}{ Total } & \multicolumn{4}{|c|}{ OHIP - 14} & \multicolumn{2}{|c|}{ Depressive Disorder (PHQ-2) } & \multirow{2}{*}{$\frac{*}{p^{*}}$} \\
\hline & & $0-8.0$ & $8.0-15.0$ & $>15^{* *}$ & $p$ & Yes $(\geq 3)$ & No $(<3)$ & \\
\hline & n (\%) & n (\%) & n (\%) & n (\%) & & n (\%) & n (\%) & \\
\hline \multicolumn{9}{|l|}{ Type of Service } \\
\hline Public & $34(39.5)$ & $29(85.3)$ & $3(8.8)$ & $2(5.9)$ & & & & \\
\hline Private & $49(57.0)$ & $35(71.4)$ & $8(16.3)$ & $6(12.4)$ & 0.63 & $10(29.4)$ & $24(70.6)$ & 0.61 \\
\hline $\begin{array}{l}\text { Does not know/not } \\
\text { reported }\end{array}$ & 33.5 & $3(100.0)$ & $0(0.0)$ & $0(0.0)$ & & $12(24.5)$ & $37(75.5)$ & \\
\hline
\end{tabular}

Note: $\mathrm{p}^{*}=\mathrm{p}$-value for chi-square or Fisher's exact test. ${ }^{* *}$ Cut-off points chosen according to quartiles $\left(<\mathrm{P}\right.$, percentile, $75, \mathrm{P} 75-\mathrm{P} 90$ and $>\mathrm{P90}$, respectively). ${ }^{* * *} \mathrm{MW}-\mathrm{Minimum}$ Wage.

Table 2. Distribution of older people enrolled in a Family Health Unit per frequency of answers: sometimes, hardly ever, and never (No Impact), often, and all the time (Impact Present), according to OHIP-14 dimensions.

\begin{tabular}{lcc}
\hline OHIP-14 dimensions & No impact & Impact present \\
& $\mathrm{n}(\%)$ & $\mathrm{n}(\%)$ \\
\hline Functional Limitation & $81(96.5)$ & $3(3.5)$ \\
Physical Pain & $70(84.7)$ & $14(16.3)$ \\
Psychological Discomfort & $78(93.0)$ & $6(7.0)$ \\
Physical Disability & $83(98.8)$ & $1(1.2)$ \\
Psychological Disability & $74(89.4)$ & $10(11.6)$ \\
Social Disability & $83(98.8)$ & $1(1.2)$ \\
Handicap & $83(98.8)$ & $1(1.2)$ \\
\hline
\end{tabular}

Regarding depressive disorder, physical disability had the strongest correlation with the PHQ-2. The other associated variables were: physical disability (0.43), followed by psychological disability, psychological discomfort, and physical pain. Next were social disability, limitation, and handicap, which had a Spearman correlation below 0.17 and were not statistically significant.

\section{DISCUSSION}

The sociodemographic profile of the studied population, with a prevalence of women with few years of schooling and low income, is similar as the one seen in other household-based studies with older people in the Family Health Strategy, and indicative of this population group's social vulnerability $[18,19]$. In addition, the population of this study follows a trend of using superior prosthesis
$(81.2 \%)$ or needing one. According to the Ministry of Health, the number of edentulous patients in need of dental prostheses in Brazil is very significant, especially among older people [15]. According to a study carried out in the European health system, $89 \%$ of the edentulous older people had total prostheses [20]. This situation remains true nowadays, in a context marked by the high prevalence of tooth loss, need for oral rehabilitation and inequality in the provision of oral health services [21].

Thus, oral health self-perception studies have been frequent, including the use of the OHIP-14 in researches with older people $[10,16]$. These researches often associate oral health to unsatisfactory quality of life, mainly in respect to the physical and mental dimensions, and emphasizing psychological discomfort. Andrade et al. [22] point out that, regardless of the clinical situation, the psychosocial dimension has a great impact on older people's self-perceived oral health. Corroborating these findings, the association between mental health and oral health stood out as a result in this study, with a significant correlation coefficient between the presence of depressive disorders (PHQ-2) and the impact of oral health on quality of life (OHIP-14). Moreover, the psychological disability and psychological discomfort OHIP-14 dimensions were the second and third most impactful, while the physical pain dimension was the first. This demonstrates how mental health is an important component in the impact of oral health on these individuals' quality of life.

The female sex presented the highest percentage of individuals with depression, in agreement with the scientific literature on the sociodemographic profile of depressive symptoms. In a survey conducted with older 
people in southern Brazil [23], the occurrence of depressive symptoms was greater among women. The study also showed that depression occurred more frequently in older people in worst economic situation, as well as those who did not work, the physically inactive, those with the worst health self-assessment and those with functional disabilities. Depression is considered the main mental disorder in older women, who have twice the chance of being depressed than men. The loss of the partner is a significant cause of trauma among women [24].

A study by Bretanha et al. [25], besides showing that depressive symptoms were statistically associated with older women, tested other variables that could be associated with depression but ended up not being significant, such as age, marital status, schooling, and selfreported hypertension or diabetes.

Older people enrolled in the Family Health Strategy have a generally positive oral health self-perception, although some betrayed shame when smiling or talking. This may have impacts on social life, also leading to nervousness or irritation, low quality of sleep, and difficulties to perform daily tasks [18].

Along with the historic increase in life expectancy, the duration of life without depressive symptoms also increased. However, Andrade et al. [22] demonstrated that the duration of life with depression was different among men and women, indicating that older women expect to live more years with depression than older men.

These themes should be explored by means of an expanded and multiprofessional approach, aimed at improving older women's health and quality of life. Even so, the data analyzed here can be an important tool for planning health actions toward the studied population.

Regarding limitations of this study, it should be emphasized that, since the sample was comprised exclusively of older people from a Family Health Unit, the results hereby presented are only representative of the studied individuals, and cannot be generalized to Ribeirão Preto's entire older population. Moreover, being a crosssectional study, no causality can be inferred.

\section{CONCLUSION}

Depressive disorders influenced the impact of self-perceived oral health on older people's quality of life, especially in the case of older women. There is a relationship between mental health and quality of life; therefore, mental and oral health care actions towards older women should be incorporated to the Family Health Strategy, with emphasis on self-care and health self-perception.

\section{Collaborators}

MUSSOLIN MG, study conceptualization, design, analysis and interpretation of data; article writing; critical review; approval of the final version. MESQUITA-LAGO LP, analysis and interpretation of the data; article writing; critical review; approval of the final version. SARAIVA MCP, analysis and interpretation of the data; article writing; critical review; approval of the final version. MESTRINER SF, study conceptualization, design, analysis and interpretation of data; article writing; critical review; approval of the final version.

\section{REFERENCES}

1. Miranda GMD, Mendes ACG, Silva ALA. Public policies challenges on the background of demographic transition and social changes in Brazil. Interface. 2017;21(61):309-20. http://dx.doi.org/10.1590/1807-57622016.0136

2. Alves DSB, Barbosa MTS, Caffarena ER, Silva AS. Caracterização do envelhecimento populacional no município do Rio de Janeiro: contribuições para políticas públicas sustentáveis. Cad Saude Colet. 2016 Mar; 24(1): 63-69. http://dx.doi. org/10.1590/1414-462X201600010272

3. Campolina AG, Adami F, Santos JLF, Lebrão ML. A transição de saúde e as mudanças na expectativa de vida saudável da população idosa: possíveis impactos da prevenção de doenças crônicas. Cad Saúde Pública. 2013; 29(6):1217-1229. http:// dx.doi.org/10.1590/S0102-311X2013000600018

4. Silva AR, Sgnaolin V, Nogueira EL, Loureiro F, Engroff $P$, Gomes I. Doenças crônicas não transmissíveis e fatores sociodemográficos associados a sintomas de depressão em idosos. J Bras Psiquiatr. 2017; 66(1): 45-51. http://dx.doi.org/10. 1590/0047-2085000000149

5. Sousa KA, Freitas FFQ, Castro AP, Oliveira CDB, Almeida $A A B$, Sousa KA. Prevalência de sintomas de depressão em idosos assistidos pela Estratégia de Saúde da Família. REME. 2017;21:e-1018. http://www.dx.doi.org/10.5935/1415-2762. 20170028

6. Anjos KF, Boery RNSO, Pereira R, Pedreira LC, Vilela ABA, Santos VC et al. Associação entre apoio social e qualidade de vida de cuidadores familiares de idosos dependentes. Ciênc Saúde Colet. 2015;20(5):1321-1330.http://dx.doi.org/10.15 90/1413-81232015205.14192014

7. Pedreira LC, Oliveira AMS. Cuidadores de idosos dependentes no domicílio: mudanças nas relações familiares. Rev Bras Enferm. 2012;65(5):730-6. http://dx.doi.org/10.1590/S0034-7 1672012000500003 
8. Urrutia CG, Ormazábal FR, Santander IE, Salvo DM. Oral health practices and beliefs among caregivers of the dependent elderly. Gerodontology. 2012; 29: e742-e747. https://doi. org/10.1111/j.1741-2358.2011.00553.x

9. Miotto MHMB, Barcellos LA, Velten DB. Avaliação do impacto na qualidade de vida causado por problemas bucais na população adulta e idosa em município da Região Sudeste. Ciênc Saúde Colet. 2012; 17(2):397-406. https://doi.org/10. 1590/S1413-81232012000200014

10. Haikal DS, Paula AMB, Martins AMEBL, Moreira AN, Ferreira EF. Autopercepção da saúde bucal e impacto na qualidade de vida do idoso: uma abordagem quanti-qualitativa. Ciênc Saúde Coletiva. 2011 July; 16( 7 ): 3317-3329. https://doi. org/10.1590/S1413-81232011000800031.

11. Prefeitura Municipal de Ribeirão Preto. Secretaria Municipal de Saúde. Sistema de Informação da Atenção Básica (SIAB). Ribeirão Preto: PMRP/SMS; 1998.

12. Slade GD, Spencer AJ. Development and evaluation of the oral health impact profile. Community Dent Health 1994; 11(1):3-11 [cited 2017 nov 10]. Available in: <https://pubmed. ncbi.nlm.nih.gov/8193981/>

13. Kroenke K, Spitzer RL, Williams JB.The Patient Health Questionnaire-2: validity of a two-item depression screener. Med Care. 2003;41(11):1284-92. https://doi.org/10.1097/01. MLR.0000093487.78664.3C

14. Freitas EV, Miranda RD. Parâmetros Clínicos do envelhecimento e avaliação geriátrica ampla. In: Freitas EV, Py L. Tratado de geriatria e gerontologia. Rio de Janeiro: Guanabara-Koogan; 2006. p. 900-909

15. Brasil. Ministério da Saúde. SB-Brasil 2010. Pesquisa Nacional de Saúde Bucal: Resultados Principais [Internet]. Brasília: Ministério da Saúde; 2011 [citado 2018 Jan 9]. Disponível em:<http://dab.saude.gov.br/cnsb/sbbrasil/arquivos/projeto_ sb2010_relatorio_final.pdf.>

16. Guerra MJC, Greco RM, Leite ICG, Ferreira EF, Paula MVQ. Impacto das condições de saúde bucal na qualidade de vida de trabalhadores. Ciênc Saúde Colet. 2014 Dec;19(12): 4777-4786. https://doi.org/10.1590/1413-812320141912. 21352013

17. De Lima Osório F, Vilela Mendes A, Crippa JA, Loureiro SR. Study of the Discriminative Validity of the PHQ-9 and PHQ-2 in a sample of Brazilian Women in the context os Primary Health
Care. Perspect Psychiatr Care. 2009; 45(3):216-227. https:// doi.org/10.1111/j.1744-6163.2009.00224.x

18. Nogueira CMR, Falcão LMN, Nuto SAS, Saintrain MVL, Vieira-Meyer APGF. Self-perceived oral health among the elderly: a household-based study. Rev Bras Geriatr Gerontol. 2017;20(1):7-19. https://doi.org/10.1590/1981-22562017020. 160070

19. Barbosa KTF, Costa KNFM, Pontes MLF, Batista PSS, Oliveira FMRL, Fernandes MGM. Aging and individual vulnerability: a panorama of older adults attended by the family health strategy. Texto Contexto Enferm. 2017;26(2):e2700015. https://doi.org/10.1590/0104-07072017002700015

20. Hoeksema AR, Peters LL, Raghoebar GM, Meijer HJA, Vissink A, Visser A. Oral health status and need for oral care of caredependent indwelling elderly: from admission to death. Clin Oral Investig. 2017;21(7): 2189-2196. https://doi.org/10.10 07/s00784-016-2011-0

21. Agostinho ACMG, Campos ML, Silveira JLGC. Edentulismo, uso de prótese e autopercepção de saúde bucal entre idosos. Rev Odontol UNESP. 2015;44(2):74-79. https://doi. org/10.1590/1807-2577.1072

22. Andrade FCD, Wu F, Lebrão ML, Duarte YAO. Life expectancy without depression increases among Brazilian older adults. Rev. Saúde Pública. 2016;50:12. https://doi.org/10.1590/S15 18-8787.2016050005900

23. Hellwig NM, Tiago N, Tomasi E Sintomas depressivos em idosos: estudo transversal de base populacional. Ciênc Saúde Colet. 2016;21(11):3575-3584. https://doi.org/10.1590/1413-8123 20152111.19552015

24. Lopes JM, Fernandes SGG, Dantas FG, Medeiros JLA Associação da depressão com as características sociodemográficas, qualidade do sono e hábitos de vida em idosos do Nordeste brasileiro: estudo seccional de base populacional. Rev Bras Geriatr Gerontol. 2015;18(3):521-531. https://doi. org/10.1590/1809-9823.2015.14081

25. Bretanha AF, Facchini LA, Nunes BP, Munhoz TN, Tomasi E, Thumé E. Sintomas depressivos em idosos residentes em áreas de abrangência das Unidades Básicas de Saúde da zona urbana de Bagé, RS. Rev Bras Epidemiol. 2015;18(1):1-12 https://doi.org/10.1590/1980-5497201500010001

Received on: $6 / 10 / 2018$ Final version resubmitted on: 20/12/2019 Approved on: 28/5/2020 